\title{
人間型ロボットのための遠隔操縦システムの開発
}

一人間型ロボットによる産業車両の代行運転への適用—

$$
\begin{aligned}
& \text { 蓮 沼 仁 志*1 中 嶋 勝 已*1 小 林 政 巳*2 } \\
& \text { 御 舩 文里*1 宮原啓 造*1 鷹 取 正夫*1 } \\
& \text { 森山尚*1 家 中良太*1 横 井 一 仁*3 }
\end{aligned}
$$

\section{The Development of a Remote Control System for a Humanoid Robot \\ - The Application of a Humanoid Robot for driving of Industrial Vehicles-}

\author{
Hitoshi Hasunuma*1, Katsumi Nakashima*1, Masami Kobayashi*2, \\ Humisato Mihune*1, Keizou Miyahara*1, Masao Takatori*1, \\ Hisashi Moriyama*1, Ryota Ienaka*1 and Kazuhito Yokoi*3
}

\begin{abstract}
A human operator can operate a robot intentionally using remote control devices. Therefore, the remote control system has the advantages that the robot can work according to the circumstances. We applied it to tele-operation of a humanoid robot that drives industrial vehicles. We have developed remote control devices that can be transported easily near the robot and remote control methods to operate the whole body of the robot, which consist of supervisory control method and master-slave control method and the operator select them suitable for the situation. For the evaluation, the tele-operated humanoid robot:HRP-1S could succeed in driving a rift truck in a standing posture and driving a backhoe in a sitting posture.
\end{abstract}

Key Words: Humanoid Robot, Remote Control System, Tele-Operation

\section{1. は じめに}

近年, 人間型ロボットの研究開発が盛んに行われている [1] [6].人間型ロボットは，人間のような外観を備えていることか ら対人親和性も高く，2 足歩行することで人間が行動する環境 を改造することなく移動でき，手を使った作業を行える，産業 用ロボットは，人間の生活環境から隔離された工場内での自動 作業が主な使用目的であったが, 人間型ロボットは, 今後到来 する高齢化社会の中で，人間と共存する環境下で利用できる次 世代ロボットのホープとして期待が大きい. しかし，現状の人 間型ロボットの適用先は主に研究教育分野, エンターテイメン ト分野に限られている。これは，現在の人間型ロボットの運動 能力では人間並みの作業を達成できないばかりでなく, 認識判

原稿受付 2003 年 5 月 9 日

*1川崎重工業（株）

$* 2$ 新エネルギー・産業技術総合開発機構

*3 産業技術総合研究所知能システム研究部門

${ }^{* 1}$ Kawasaki Heavy Industries, Ltd.

${ }^{* 2}$ New Energy and Industrial Technology Development Organization

${ }^{* 3}$ Intelligent Systems Institute, National Institute of Advanced Industrial Science and Technology
断能力も様々な環境下で作業を遂行するには不十分であること に起因していると思われる。

経済産業省・NEDOでは, 人間型ロボットの実作業への適用 可能性を探求する目的で「人間協調・共存型ロボットシステム プロジェクト (Humanoid Robotics Project, 略称HRP)」を, 1997 年から 5 年間に渡り実施した $[7]$. 本プロジェクトでは, 前 期 2 年間に研究開発の共通基盤となるプラットフォームを開発 し, 後期 3 年間で五つの応用分野での実用化を促進する応用研 究開発を行った．HRPの応用分野の一つである「産業車両等代 行運転分野」では, 人間型ロボットが直接作業を行うのではな く，産業車両を人間と同じ要領で操作することにより，作業を 遂行することを目標とした $[8]$. 産業車両を運転することにより， 人間型ロボットは自身の運動能力の拡大を図り, 人間並みの作 業を行うことができるからである. しかし, 認識能力の欠如は 補えないため, 人間型ロボットの操作には, 遠隔操縦システム を適用することとした。

遠隔操縦システムは, 海中や宇宙空間, 原子炉内など人間が 直接作業できない場所での作業を行うロボットの操縦方法とし て,これまで数多く研究開発されてきた $[9]$. 筆者らも，これま で等慣性マスタアームの開発 [10], 水中マニピュレーションシ ステムの開発 [11], パラレルリンクマニピュレータの開発 [12] 
において, 遠隔操縦システムの研究開発を行ってきた。遠隔操 縦システムは, 人間が直接作業指示を行うので, 状況に応じた 臨機応変な対応ができる。このため，人間型ロボットの自律化 を図っていく上に拈いても, 通常作業時に発生した異常状態か らの回復手段や，自律制御プログラムを作成する前にそもそも ロボットの機構が所望の動作を実行できるかどうかを実際に確 認する手段として利用可能である.

筆者らは, HRP 前期において, 操作者への高度な臨場感の 提示に重点を置いた人間型ロボットの遠隔操縦システム「スー パーコックピット」を開発している [13]. そこで, スーパーコッ クピットを用いて, 産業車両の代表的な運転姿勢の一つである 「立ち姿勢」で運転できる「立ち姿勢運転型フォークリフト」の 人間型ロボットによる代行運転を実施した [14].

しかし，スーパーコックピットでは，立ち姿勢での作業実行 を前提として開発されており，着座動作や，歩行以外の足動作 の遠隔操縦は実行できず，産業車両のもう一つの代表的な運転 姿勢である「着座姿勢」で運転する「着座姿勢運転型バックホ ウ」の代行運転には適用できなかった．また，近年通信技術の進 歩から遠隔地との通信带域も広がっているが, 通信時間遅れが 遠隔操作性を低減することを考慮すると, 産業車両の代行運転 のような状況が刻々と変化するような作業では, 操作者の安全 性と快適性が確保される範囲で，できるだけ現場に近い場所に 遠隔操縦システムを設置することが望ましい。すなわち，遠隔 操縦装置には可搬性が必要であり，この点からもスーパーコッ クピットは不適当であった.

そこで, 我々は新たな人間型ロボットの遠隔操縦システムを 研究開発した。これに際しては, 人間型ロボットは, 人間同様, 様々な作業ができることを目標に開発されているため, 産業車 両の運転だけでなく，付随作業である周辺の探索や車両の点検・ 修理などを行うことも可能である点に注意して，産業車両を運 転する人間型ロボットの遠隔操縦システムの開発ではなく, 人 間型ロボットの汎用的な遠隔操縦システムの開発を目指し, そ の機能を人間型ロボットの一つの応用である産業車両の代行運 転により確認することを目標とした。

本論文では，新たに開発した人間型ロボットのための遠隔操 縦装置と，それを用いて産業車両の代行運転を円滑に行うため の遠隔操作手法について述べる。特に, 全身同時動作や操作者 の負担軽減のために開発した操作手法の有用性について, 産業 車両の遠隔操縦実験によって示す。まず，第 2 章で開発した遠隔 操縦装置のハードウェア構成を示す。第 3 章では開発した遠隔 操縦システムの四つの基本機能をスーパーコックピットと比較 しながら示す。さらに，第 4 章で遠隔操作手法の検討内容，第 5 章で実証実験と実験から得られた遠隔操縦システムへの知見 を，それぞれ示し，第6 章でまとめる.

\section{2. 遠隔操縦装置のハードウェア構成}

新たに開発した遠隔操縦装置の構成は, 操作者の手で操作す るマスタアーム，操作者の足で操作するマスタフット，ロボッ トに搭載されたカメラからの視覚情報を操作者に提示する三次 元視覚提示ディスプレイ，操作情報を提示するグラフィックス. ユーザ・インタフェース (GUI) 提示ディスプレイ, および，視
覚処理装置, マスタアームの制御装置とした。遠隔操作装置の 全体構成を Fig. 1 に示す.

遠隔操縦装置は可搬性を重視してユニット構成とし，マスタ アームは $20[\mathrm{~kg}]$ 以下, 制御装置は 1 ユニット $15[\mathrm{~kg}]$ 以下の五つ のユニットに分割でき，それぞれ一人で持ち運べるようにした。

以下, 開発した遠隔操縦装置の主な構成要素であるマスタアー ムとマスタフットについて述べる。

\section{1 マスタアーム}

スーパーコックピットのマスタアームは外骨格型の 7 . 自由度 であり，完全な相似型ではないが，ロボットの腕に近い形状で あった。しかし，外骨格型とするため大型となり，重くなってし まった。そこで，新たに開発したマスタアームでは，軽量化の ために 6 自由度異構造とした。マスタアームの手首機構は, 操 作者がトルクと力を区別して感じることが容易であるように設 計した $[15]$. また, ダイレクトドライブ型モータやバランス重 りを導入し, 力 ノトルクの提示性能が高い「感度のよい」マス タアームを実現した。さらに，マスタアームの把持部には手腕 操作用のトリガスイッチと, 機能切り替えや指示操作用の 5 方 向スイッチを配置したＦig. 2 にマスタアームの全体図を示す.

2.2 マスタフット

マスタフットは, 操作者の足首位置で遠隔操作するための装置 である. 足首位置の検出には, シェイプテープ (Measurand 社. 製，S1280CS）を使用している.シェイプテープは長さ約 $2[\mathrm{~m}]$ のテープ状をしており, 先端から約 $50[\mathrm{~cm}]$ までの範井で位置と 姿勢が計測できる。そこで，テープ先端を足首に固定し，テープ の途中（計測可能部分の端）を基準位置に固定することで, 足

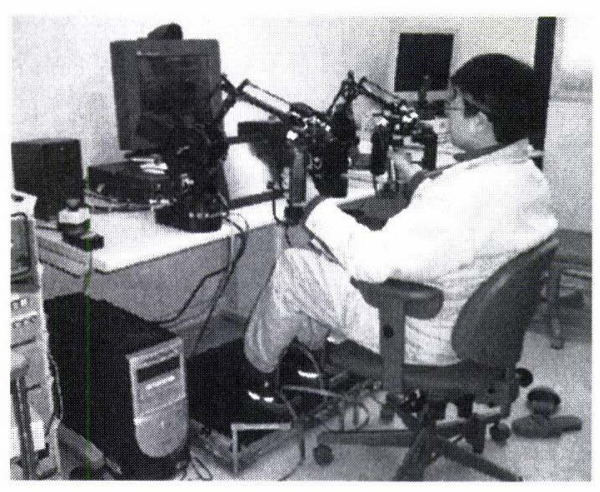

Fig. 1 Portable remote control system

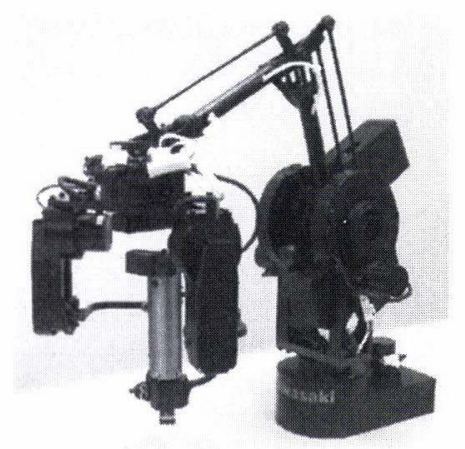

Fig. 2 Master arm 


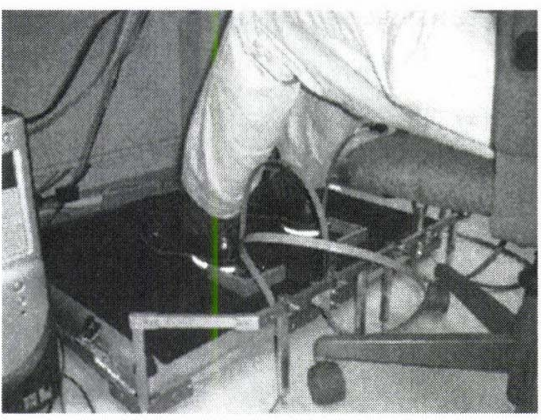

Fig. 3 Master foot

首の位置を計測するようにした。テープ状であるので，軽量か つ，足の動きを拘束することもないのが特長である。なお，足 は手と違い微妙な力感覚に欠けるため力提示は行わないことと した。Fig. 3 にマスタフットの使用状態を示す.

マスタフットはテープ状であるため, 方向により精度が異な る。そこで人間型ロボットが着座時に足を動作させる上下前後 方向に精度が高い設置方向を選択するとともに, 三次元計測に よるキャリブレーションを行い, 左右 $60[\mathrm{~mm}]$, 前後 $150[\mathrm{~mm}]$, 上下 $90[\mathrm{~mm}]$ の計測範囲で $\pm 5[\mathrm{~mm}]$ 以下の計測精度を得ている.

\section{3. 遠隔操縦システムの基本機能}

人間型ロボットの遠隔操縦システムにおいて, 重要な要素は 「臨場感」と「自己投射性」である。「臨場感」とは，人間の知 覚認識能力を生かすために, ロボットの作業現場の状況を操作 者に分かりやすく伝えることである。また「自己投射性」とは， ロボットの動かし方を操作者自身の経験から直接的に理解して, 操作者の作業スキルを生かすことである. 人間型ロボットは, そ の形態が人間と相似であるがゆえに，操作者の知覚認識能力や 経験的な動作技能を直接利用できる利点がある.

開発した遠隔操縦システムでは，「臨場感」に関しては，操作 者の知覚認識能力を生かすために用いる「操作者に現場の情報 を与える機能」によって実現し，「自己投射性」に関しては，操 作者の手腕操作によってロボットの動作を指示する「操作者の 手腕による操作機能」, 操作者にロボットや操縦装置の情報を提 示し, 操作者が操縦方法を選択するために用いる「操作情報を 提示 /入力する機能」, 操作者の手腕操作とは別に同時に操作し てロボットの動作を指示する「手腕操作と同時に他の部位を操 作する機能」によって実現した。

以下，スーパーコックピットと比較しながら，開発した遠隔 操縦システムにおける各機能の実現方式について示す.

\section{1 操作者に現場の情報を与える機能}

遠隔操縦作業では, 操作者がロボットの作業環境の状況を把 握し, 動作の判断を行う。そのため, 操作者に環境の情報を伝 えることは重要である。特に，人間の知覚情報の大部分を占め る視覚情報は遠隔操縦をする上で必要不可欠である。また, 聴 覚情報の提示／入力は，視覚情報だけではわからない作業環境 との接触検知や, 作業現場での意思伝達に有効である.

スーパーコックピットでは, Fig. 4 に示すように歩行移動時 には操作者の視野の大部分を占める 9 面立体ディスプレイ, 腕

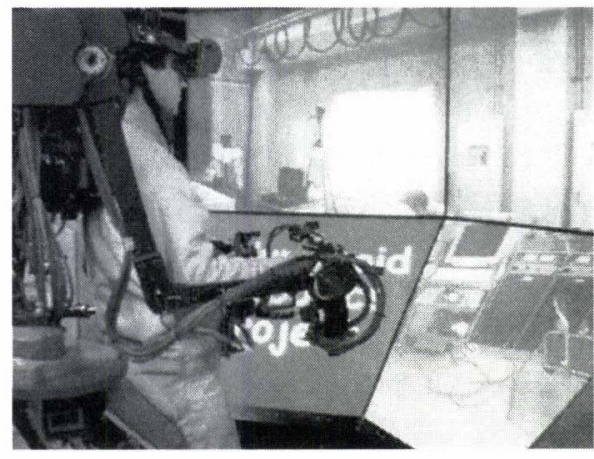

Fig. 4 Super cockpit system

作業時には操作者の頭部にヘッドマウンテッド・ディスプレイ （HMD）を装着して視覚情報の提示を行っている。また, 聴覚 情報は立体音響装置により周辺音情報の提示を行っている。さ らに, ロボットの腰部の運動を加速度や位置変化により操作者 に体性感覚を提示することも行っている。これらの装置により, 操作者はあたかもロボットの中にいるような高い臨場感を得る ことができた。しかしながら, 高い臨場感を操作者に与えるに は操作者の感覚器の受容範囲を提示装置で覆う必要があるため, 装置が大掛かりになってしまった。

一方, 開発した遠隔操縦システムでは, 可搬性を重視し, 特 に装置規模が大きくなる体性感覚の提示は行わず，操作者は着 座姿勢で操作することにした，視覚情報は，ロボットの頭部ス テレオカメラの映像を立体視ディスプレイで提示した。立体視 ディスプレイには, 専用めがね不要のタイプを採用し, HMD 等を装着する手間を省くとともに, 操作者の視界を提示映像で 占有することを避けた。 また，聴覚情報はロボットに搭載され たステレオマイクで拾った音情報を, $2 \mathrm{ch}$ ステレオスピーカで 提示するに留めた。

\section{2 操作者の手腕操作による操縦機能}

対象物を扱う作業のように，実時間で自在に精度よくロボッ トの手先を操る必要がある作業では, 人間の手腕動作をロボッ トの手腕動作として利用できるマスタスレーブ制御方式が適し ている。また，環境との接触を伴う作業では，接触力・トルク を操作者の手腕に感度よく直接伝達することが, 作業を確実に 行うために有効である。ささらに，手腕作業では力とトルクの方 向・大きさによって対象の動かし方が異なるため, 力とトルク の識別が精度よくできることも重要な要素である.

スーパーコックピットでは, 操作者の腕の動作範囲と, ロボッ トアームの動作範囲がほぼ同等になるように設計した 7 自由度 外骨格型マスタアームを手腕操作機器とし, 操作者の手先位置 姿勢がロボット手先の位置姿勢と一対一に対応するようなバイ ラテラル・マスタスレーブ制御方式を用いた。このシステムは 高い臨場感の提示とともに，操作者がロボットの中に入り込ん だような感覚で操縦することができ，高い自己投射性を実現し た。しかし，マスタアームが大型化しただけでなく，操作者に 対する力・トルク伝達感度が低下した。これは以下の理由によ る.スーパーコックピットのマスタアームは, 外骨格型構造を 採用したため, その動作範囲内に操作者自身と干涉する領域が 
多いことから，マスタスレーブ制御則に制御安定性に優れた並 列型制御方式 [16]を用いた，本方式は，操作者がマスタアーム に加える力である操作力（マスタアーム把持部のカセンサで計 測）と，スレーブアームが環境に与える力（スレーブアーム手 首部のカセンサで計測）の力偏差を 0 にするようにマスタアー ムとスレーブアームの位置を制御する方式である。しかし， マ スタアームの慣性や軸の摩擦が大きくなったため, マスタアー ムの位置の応答性が十分確保できず，スレーブアームとの間で 力偏差が残ってしまった，その值は, 操作速度に応じて大きく なり，実験では $1 \sim 6[\mathrm{~N}]$ の範囲であった。

一方, 開発した遠隔操縦システムでは, マスタアームを操作 者の前面から対向する型に配置したため, 操作者との干涉領域 が少ないことから，応答性に優れた力逆送型制御方式を用いた。 本方式は, スレーブアームが環境から受ける力をマスタアーム で再現するように開ループでトルク制御するものである．開発 したマスタアームは, 小型で慣性も小さいことに加えて, 各軸 の摩擦を低隇することにより, 力の再現性を向上させ，スレー ブアームの提示力との力偏差は $1[\mathrm{~N}]$ 以下と, 操作性が向上し た。ロボットの手先位置姿勢は, マスタスレーブ制御方式で操 作することにし, ロボットのて長自由度の使い方は別途指令す るようにした。 また, 操作者の椅子に, 操作者の疲労軽減と手 先動作の精度向上の面で有効である肘置きを設置した。

\section{3 操作情報を提示/入力する機能}

産業車両の運転では, 乗り込みのための移動だけでなく，運 転席への着座, 手足による運転操作を行うため, 全身動作や足 機能の変更に対応できる遠隔操縦システムが必要である。この ためには，様々な状況に適した遠隔操縦手法を組み合わせた操 作手法が必要である，特に，人間の操作入力を支援する自律機 能の付加や, 状況に適した自律動作の選択が容易に行えること が重要だと考える.

遠隔操縦を円滑に進める手法として, “Shared Autonomy” [17] や “Supervisory Control” [18] などの概念が提案されてい る.しかし, 現状では, 状況に応じて自動的に適した操作手法 を選択する手法は確立されていない。したがって，ロボットの 制御情報 - 操作手法の状況を操作者が把握し, 実現可能な操作手 法を操作者が状況に応じて任意に切替できることが必要である。

スーパーコックピットでは，遠隔操作対象とする人間型ロボッ ト HRP-1が，その下半身に関しては歩行のみしか指令できな い仕様であったため, 上半身の遠隔操作手法は, 操作者のハン ド, 腕, 頭の動きをロボットの各部の動作に対応させるマス夕 スレーブ制御方式, 下半身の遠隔操作手法は, 音声認識やマウ スを使って歩行指令を出す移動コマンド方式に固定されていた。

開発システムでは，スイッチ操作により各種操作手法を切り 替えられるようにし, GUIにロボットの全身姿勢状態, 操作手 法の選択状態, 操作手法に合わせたセンサ情報を提示するよう にした，選択できる操作手法については 4 章で詳細を述べる。

\section{4 手腕操作と同時に他の部位を操作する操綐機能}

人間型ロボットの遠隔操䋛では, 手腕操作での指示動作と同 時に, 手腕操作ほどの精度は望めなくても他の部位の動作を直 接指示したい場合がある。この場合, 操作者による手腕以外の 動作部位を用いた操作方法が必要であり, 操作者の手腕動作を
妨げない入力装置が望ましい。

スーパーコックピットでは, 上半身の動作は操作者の動きに 連動した操作方式であったため, 手腕と頭部の同時操作は容易 であったが, 下半身の動作は歩行のみを考慮したので, 足の操 作は考慮されなかった．また， ロボットの姿勢を維持するには， 操作者自身の姿勢も維持しておく必要があったため, 長時間の 作業には操作者の負担が大きい問題があった。

開発システムでは, 腕操作以外の頭部搭載カメラのパン・チ ルトやハンドの開閉はマスタアームの手元スイッチで操作する ようにした。また, 着座して運転する人間型ロボットには, 手 腕動作だけでなく足動作が必要であることから, 直感的な操作 方法として, 足で操作ができる「マスタフット」を開発した。操 作者は着座状態で操作するので, 手腕操作と同時に使えるマス タフットは, ロボットの足動作指示に有効である。また, 頭部 搭載カメラのパン・チルト操作もマスタフットを用いて, 手腕 操作と同時に行えるようにし，操作性の向上を図った。

\section{4. 遠隔操作手法}

人間型ロボットの全身動作遠隔操作法として, 操作者の負担 が軽隇されるように, ロボットの作業内容に応じて以下の二つ の操作方式を切り替えるようにした。

(1) 管理制御方式：産業車両への乗り込み時の歩行動作や着座 動作のように一連の全身動作を指令する場合や，ロボット の視覚提示画面で操作者が指示した任意の位置に手先を自 動的に移動させる場合（視覚補助機能）に用いる．本制御 方式では，操作者の指令に基づき事前あるいは実時間で生 成されたロボットの全身動作パターンを，操作者の判断で 再生開始あるいは止められる。

（2）マスタスレーブ制御方式：産業車両への着座後の両腕両足 の操作や頭部カメラの操作など, 操作者がマスタアームや マスタフットの操作により直接操作する場合に用いる. 本 制御方式では，入力装置を通じた操作者の指令により実時 間でロボットへの指令を生成し，ロボットを制御する。ま た，手先·足の操作はそれぞれマスタアームとマスタフット で行うが，マスタアーム把持部のトリガスイッチを押し続 ける間, マス夕側の変位をスレーブ側に伝達する形とした。 以下では，上記の操作手法を産業車両の運転作業を行うロボッ トに適用した例を示す。

\section{1 着座動作（管理制御方式とマスタスレーブ制御方式の 切替)}

人は椅子に座るとき，バランスを取りながら憼部を下げるの ではなく，座る直前にバランスを崩して繁部を椅子の座面に乗 せる，そのとき，剧部は衝撃を和らげるクッションの役割を果 たす．しかし，遠隔操縦の対象とした人間型ロボット HRP-1S には人の熬部に相当する部分がなく，衝撃を和らげる効果は期 待できない，そこで，椅子の座面に靔部を乗せる動作はバラン ス状態で行い，その後に足の位置を変えて安定な着座状態とす る 2 段階の動作を行わせることとした。この方式は高齢者の着 座方法に近い。

まず，第1段階では，HRP-1S 全体の重心位置を調整してバラ ンスを保ちながら着座位置に䳑部を接近させて椅子に座る。こ 


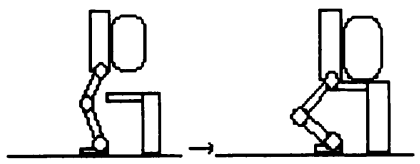

Seating with keeping its upper body upright

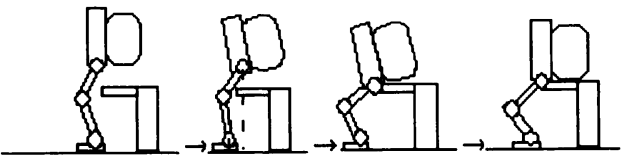

Seating with bending its upper body

Fig. 5 Two way methods for seating

のような方法で椅子に座ろうとするとき，Fig.5に示すように 上体を直立させたままでは，慜部はほほ真下に降りる，着座し た後の安定性を考えると蟹部の位置に対し両足ができるだけ前 にあるのが望ましい。そこで，上体を前屈みにし，その分筒部 を後ろに下げてバランスを取って着座し，着座後に上体を直立 に戻す方法を採用した。

全身動作軌道は，静的バランスを取った二次元面内でのパター ンを作成後，シミュレータで動的バランスを確認して作成した。 着席の動作パターンは, 筒部と椅子の接触位置と着座開始姿勢 により生成できるので，異なる着座位置に対してもパラメー夕 を変更することで，即座に対応することが可能である．作業時に は管理制御方式により着席動作パターンを再生することとした。

第 1 段階の着席状態では，両足の着地点と繁部の着地点で作 る支持多角形が小さく，運転作業時の傾きや振動に対する安定 性に心配があった。そこで，第 2 段階として，両足を前に移動 させ，ロボットの支持多角形を大きくすることを検討した。

足位置を動かすには，足を地面に着いたまま動かすすり足と 足を地面から上げて動かす方法がある．HRP-1S の足裏はゴム 製で摩擦係数が大きく，すり足では動かない．また，着座後に 片足を上げると，足毫が離れる前に HRP-1S が傾く．これは督 部が小さく片足を上げると, 他方の足の着地点と督部で構成す る支持多角形が小さくなり， ロボット重心の床面への投影点が 支持多角形の外になるためと考えられる。 そこで，足を上げる 側の手を座席付近の適当な位置に着いて，負荷を支持すること を検討した。

手で体を支えるには，手の負荷限界と，局関節で発生できる トルクの限界という二つの制的がある。手の負荷限界をカセン サの保護の観点から力センサの定格值である $100[\mathrm{~N}]$ とし, 着手 に適した位置を計算した。その結果，Fig.6のように右足を移 動する場合での右手の着手位置を決定した，図の XY平面は床 面を表しており，各表示点は床面への投影点である。直線 $\mathrm{A}$ は, ロボットが右足を上げた場合に，ロボット座標原点付近を重心 位置とした重力によって，ロボット筒部接触点の中心と仮定し た殽部着地点と，左足の足裏中心と仮定した左足着地点を結ん だ直線周りに生ずる転倒モーメントを，右手の負荷限界である $100[\mathrm{~N}]$ の負荷で受けることができる右手の着手位置の集合であ る. 右腕の肩関節に発生トルクの制約がなければ, この直線 $\mathrm{A}$ より下部に右手を着くことで $100[\mathrm{~N}]$ 以下の負荷でロボットは支 えられる。一方, 曲線 Bは右手に $100[\mathrm{~N}]$ の負荷がかかった場合

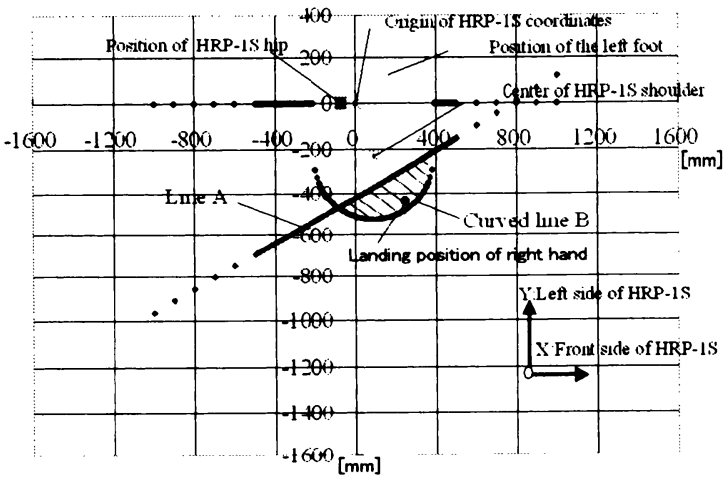

Fig. 6 Hand position for moving foot position

に, 静的な釣り合い状態で, 右腕の肩関節の発生トルクが最大 となる右手の着手位置の集合である。したがって，ロボットの 右手で $100[\mathrm{~N}]$ の負荷を受けるためには, 曲線 Bより上部に右手 の着手位置を選ぶ必要がある。よって, 直線 $\mathrm{A}$ と曲線 Bで囲む 範囲内が右手の着手位置として適した領域になる，HRP-1Sの 手腕動作範囲内で着手できる位置を実機で検討した．Fig. 6 に 着手可能領域と実際に着手した位置を示す。

\section{2 アーム干涉回避動作（管理制御方式とマスタスレーブ 方式の融合）}

HRP-1S のアームは 7 自由度あるので，腕姿勢を指示するに は手先の位置姿勢のほかに一つの尣長自由度の設定が必要となつ た。 そこで, 圥長度の指標として「时角度」[20]を用いて时位置 を設定した，时角度とは，肩関節中心と手首関節中心を結ぶ直 線 L に対してロボットの固定座標系での鉛直下方に肘関節が存 在する場合を时角度 0 とし, 肘関節の位置が直線 $\mathrm{L}$ を中心軸と して回転した角度 $\theta$ の方向に存在するとき肘角度 $\theta$ とする角度 である。

HRP-1S のアームの遠隔操縦では，マスタスレーブ制御方式 で与えられる手先位置姿勢指令と，操縦者が同時に設定する时角 度指令から各軸位置指令を計算する。このとき, 肘角度指令の増 隇はマスタアームのスイッチ操作で行い, 手先位置姿勢指令は, マスタアーム把持部のトリガスイッチを操作者が押し始めた時 点のマスタアームの位置姿勢からのマスタアームの位置姿勢変 位を HRP-1Sへの手先位置姿勢変位指令值とし，トリガスイッ チを押し続ける間，トリガスイッチが押された時点の HRP-1S の手先位置姿勢にその指令值を加えることで, HRP-1S の手先 位置姿勢指令とする，肘角度により，肘の上下操作をイメージ して，操作者は手先の位置姿勢を保持したまま，肘位置の変更 ができる。

HRP-1S のアーム動作範囲には，上腕部と胴体部が干涉する 領域がある。この干涉領域は HRP-1S の視覚カメラで直接操作 者が認識できないので, HRP-1S の自律動作として, 时角度を 自動更新して干渉回避する機能を管理制御方式で付加した。こ の機能では, Fig. 7 に示すように，时角度指令と手先位置・姿 勢指令から各関節角度指令を計算し, 指令された肘関節の位置 がHRP-1S の上腕部と胴体部が干涉する領域の近傍にあるとき， 时角度指令を自動更新して时関節の位置を干涉しない位置に移 動させる。また，干渉しない領域では时角度で指定された肘関 


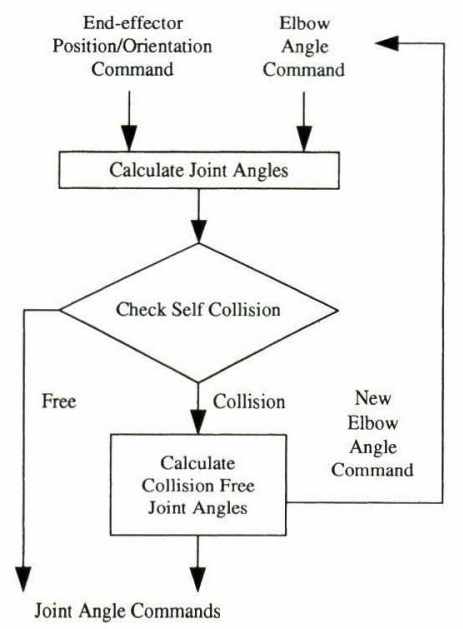

Fig. 7 Redundant control for the arm operation

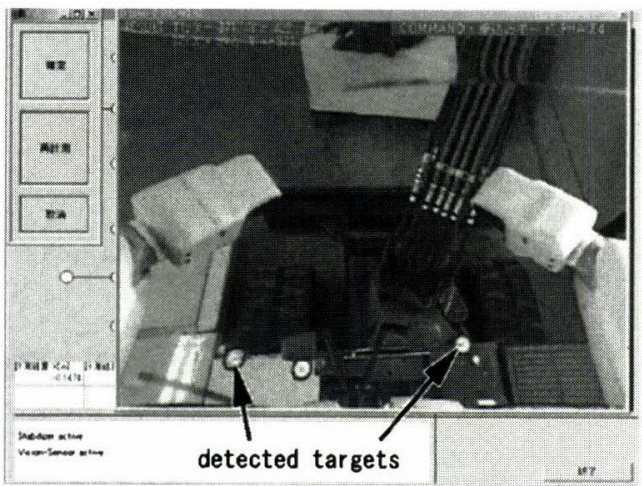

Fig. 8 View of image processing

節の位置に戻す。これらの切り替えは各関節角度指令が急変し ないように行った。

\section{3 視覚補助動作（管理制御方式）}

人が物をつかむ場合を考えると，目で見た場所に手を無意識 に動かすことができ，決して各関節の動きを意識するわけでは ない，それと同様に，遠隔操作においてもロボットの視野画面 上で指定した場所にロボット手先を誘導する機能が操作者の負 担軽減に有効と考えた。この場合，画面上で指定した位置をス テレオカメラの画像処理で距離を計測し，ロボットの各軸角度 から相対目標位置を計算する [19].

また，ロボットが産業車両に乗り込む場合，操縦席の各種設 置物との干涉を回避してロボットが移動可能な経路が限定され ているだけでなく，着席動作に必要な立ち位置の精度が歩行の 精度だけでは確保できない。そこで，産業車両の床面に設置し たターゲットを視覚認識処理し、ロボットの現在位置を計測し て, 目標歩行位置までの移動指令值を生成するようにした，操 作者はFig. 8 に示す計測結果を見て，正しいターゲットを認識 しているかを判定し，歩行動作の指示をする．視覚処理の補助 により，操作者は精度よく歩行指令を行うことができる。

\section{5. 実 証 実 験}

開発した遠隔操縦システムを用いて操縦する人間型ロボット
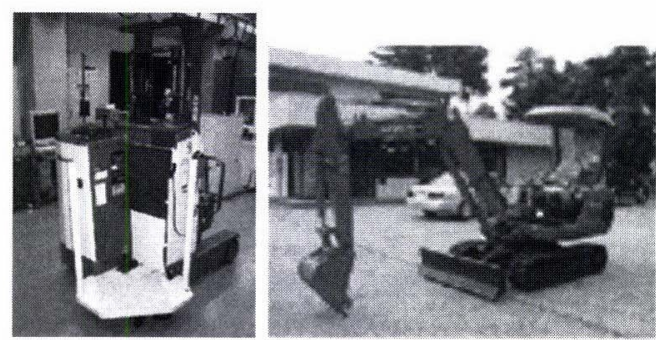

Fig. 9 Industrial vehicles
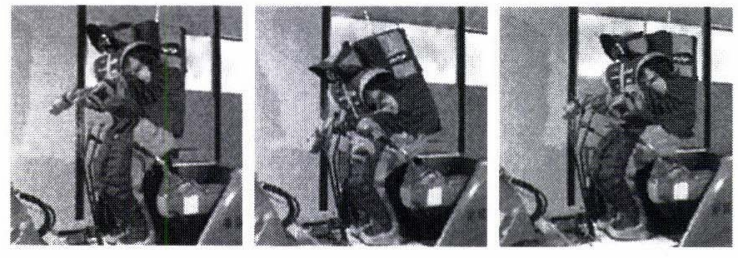

Fig. 10 Seating motion
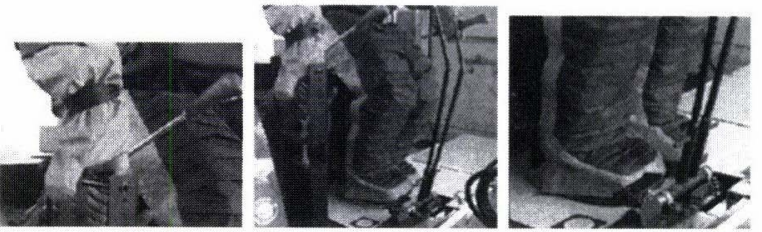

Fig. 11 The right hand putting on a device and the foot moving forward

HRP-1S が産業車両を運転する実証実験を行った。使用した産 業車両は, 産業車両の代表的な運転姿勢を要する立ち姿勢運転 型フォークリフト (二チユ, FBR9-60, Fig. 9 左), 着座運転 型バックホウ（日立建機，EX25，Fig. 9右）を用いた。また, HRP-1S の機構的な制的のため, 各車両に小規模な改造を施し た。フォークリフトでは, 操作レバーの長さ・角度変更, ハン ドル操作力・走行速度の低減, 搭乗台の面積拡張を行った。ま た, バックホウでは, 操作レバーの長さ・角度変更, 座席をロ ボット専用座席に置換, 着手用治具と乗込用ターゲットマーク の設置, キャノピー・フロアマットの撤去を行った。

\section{1 着座実験}

HRP-1Sの着座動作をバックホウ実機で検証したＨRP-1S の腎部は着座用に設計されていないので，バックホウ座席に着 座用シートを設置しているＦig. 10 に示すように，バランス を崩すことなく着席できた。操作者は管理制御方式で着席動作 の実行を指示した。動作は GUIで監視した。

次に,Fig. 11 に示すように右手を着いて，右足を持ち上げ 前方に移動させた，右足を前方に移動させた場合，右足と简部 で構成するロボットの支持多角形が大きくなり，ロボット重心 の床面投影点が支持多角形内に入るため, 左手の支持なしに左 足を移動させることができた．Fig. 12 に右足が移動したとき のデータを示す，右足が持ち上がったときに，左足と右手に荷 重がかかり，右足が着地したときに右手の荷重がなくなる。

操作者は, 右手の着手用治具付近への移動を管理制御方式, 着手動作と足の移動をマスタスレーブ制御方式で行った. 足の 動作は，おおまかな位置移動をマスタフット，微妙な位置移動 


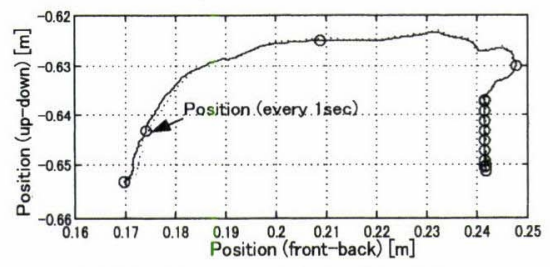

(a) Trajectory of the right foot

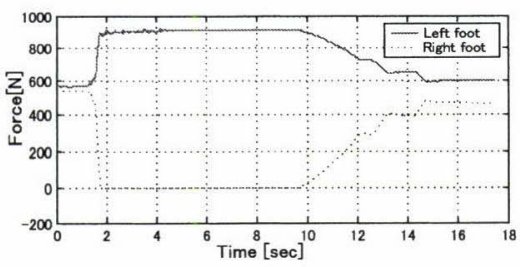

(b) Reaction force of each foot

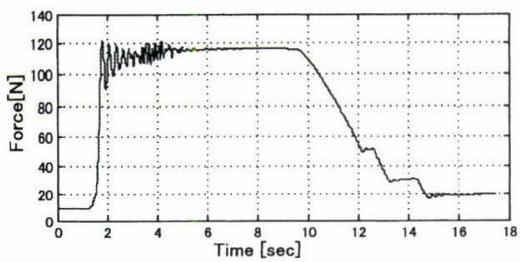

(c) Reaction force of the right hand

Fig. 12 The trajectory of right foot position and trend data of feet force and right hand force

による足にかかる荷重の調整をスイッチ操作で指示した。着席 状態は，座席の傾きや着席開始位置のずれから毎回異なるが, 足の動作をマスタスレーブ制御方式で行うため, 毎回荷重を適 切に調整して安定して着座することができた。 マスタフットに よるマスタスレーブ制御方式では, マスタアーム把持部のトリ ガスイッチを操作者が押し始めた時点のマスタフットの位置か らのマスタフットの位置変位をロボット側への足位置変位指令 值とし，トリガスイッチを押し続ける間，トリガスイッチが押 された時点のロボットの足位置にその指令值を加えることでロ ボット側への足位置指令とする。また, 運転作業終了後, 座席 から立ち上がる起立動作も，着座時の逆手順で足位置を移動さ せ，着席完了姿勢に戻して，着座動作の逆軌道を再生する管理 制御方式で立ち上がることができた。

\section{2 アーム作業実験}

産業車両の運転は，一般にレバーやハンドルを操作して行う。 使用したフォークリフトでは，レバーはロボット正面に位置した ため, 視野に入りやすく操作が容易であった。一方，ハンドル操 作は，ハンドルの接線方向に力をかけて回転させるために，手先 姿勢や操作力の調整が必要で操作の難易度が高かった。 Fig. 13 にハンドル操作時の左手先位置と手先がハンドルに加えた力ベ クトルを示す. カベクトルから接線方向以外の力を調整しなが らハンドルを回していることが分かる. 力提示なしではハンド ルに大きな力が加わり安定に操作できなかった.

バックホウの運転はレバー操作のみであるが, 前方に位置す る走行レバーに比べて，バケット位置を操作するレバーの操作 の難易度が高い，なぜなら，HRP-1Sの動作範囲下方に位置す るため, アーム動作範囲限界や HRP-1S 本体とアームの干渉を 考慮して操作する必要があるからである. Fig. 14 に走行レバー

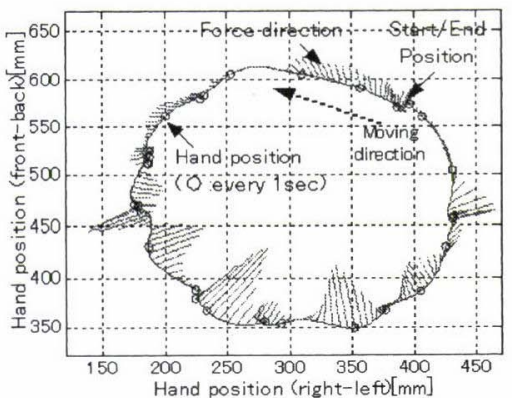

Fig. 13 The trajectory and force vector of left hand at the handle operation of the lift truck

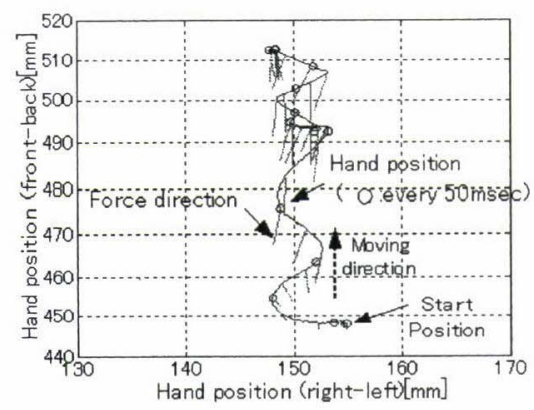

Fig. 14 The trajectory and force vector of the left hand at lever operation of the backhoe
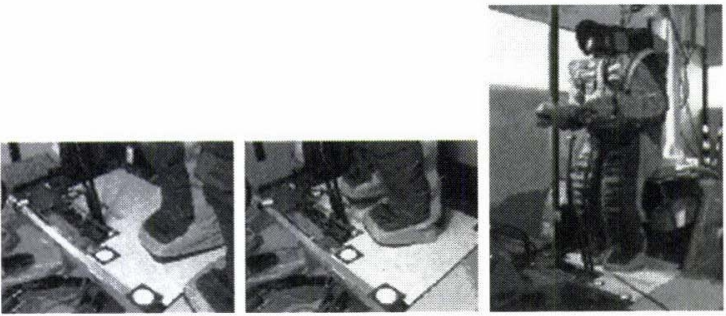

Fig. 15 The motion of riding on the backhoe

操作時の左手先位置と加わった力ベクトルを示す。レバーを前 方に移動させると，レバーの操作反力が加わる，操作者は，レ バー反力を感じながら，レバーの動作方向を認識し，HRP-1S の手先位置を調整している.

\section{3 乗り込み実験}

バックホウ座席への乗り込みを管理制御方式で行った。移動 経路を視覚で計測するために，床面にターゲットマークを 4 箇 所設置し，目標移動位置との相対関係を設定した。視覚計測の 位置精度は約 $\pm 1[\mathrm{~mm}]$, 歩行移動を含めて平均 $10[\mathrm{~mm}]$ で位置 決めすることができた，Fig. 15 に乗り込み動作の様子を示す.

操作者は, 移動位置によって計測するターゲット，歩行方法の 組を選択し, 計測結果を判断して歩行動作を指示している. 本 手法を用いることにより，異なる車両の乗り込み動作について も, ターゲットマークの配置と歩行方法を変更することで対応 が可能になる。また, 視覚処理の補助により, 操作者は位置決 め精度の必要な動作に対して操作負担少なく指示することがで きた。視覚計測ができない場合は, 移動位置を直接指示する操 作方法を用いる。 


\section{4 総合作業実験}

フォークリフトとバックホウ，二つの産業車両に対して，一 連の作業を行う遠隔操作実験を，開発した遠隔操縦システムを 用いて行い, 人間型ロボットが異なる産業車両の運転作業を行 えることを確認した。

フォークリフトの運転作業は，人が運転する場合の 3 倍以内と いう目標時間を設定して, 所定の作業を 2 人の操作者で行った. 内容は前進，荷物の持ち上げ，後進，方向転換，所定場所への 荷物の設置, 後退である。本実験は 2002 年 3 月の ROBODEX 2002 の会期中 12 回実施したデモにおいて公開した.Fig. 16に デモの様子を示す.

バックホウの運転作業は, 屋外環境に設置したバックホウで 操縦席への乗り込み, 着座, 運転作業までを行った。走行・掘 削作業を行う様子を Fig. 17 に示す。本実験は, HRP-1S を遠 隔操縦して行い，人が直接運転して一連の作業を行う時間の約 3 倍以内で行うことができた。 人の 3 倍という作業時間は十分 に満足できるものではないが，応用の初期段階でもあり，人間 型ロボットで産業車両を運転させることに対する今後の可能性 を示せた。

作業時間の違いは, 運転操作開始までの乗り达み・着座動作 では, ロボットの移動能力・全身動作において人間並みの動作 を実現できていないことが問題である，運転操作では，レバー の操作速度がロボットの遠隔操縦では人間の直接操作に比べて 遅いことが問題である。これは，人間が直接運転操作するとき には，指先や手のひらを巧みに使い，レバーの操作力を微妙に 調整しているが, ロボットのハンド部は 1 自由度のグリッパ機 構なので, 腕全体の動作で操作力を調整するからである.

また，長時間，レバー操作を行うと，レバーの把持位置がず れて操作性を損なうことがあった。これは，ロボットのハンド 部には，すべりを検出するセンサがなく，レバーに平行な位置 のずれは手先反力・モーメントだけでは操作者が認識しにくい ことが原因である。

今回の実験では，産業車両連転の中の定型作業に管理制御方 式を採用し, 各作業段階で必要な操作手法をスイッチで簡単に

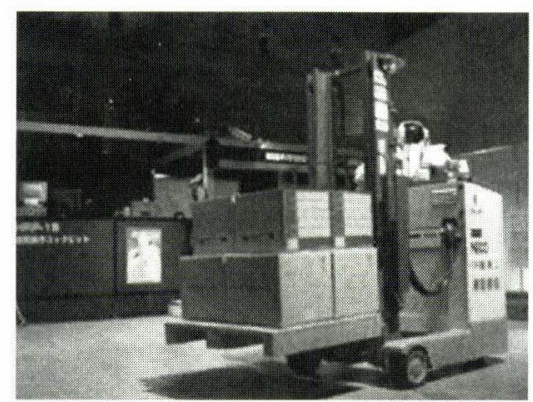

Fig. 16 Demonstration in ROBODEX 2002
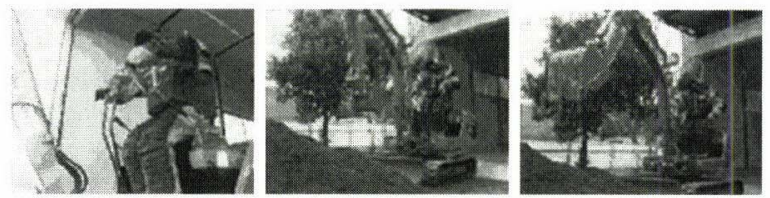

Fig. 17 The tele-operated HRP-1S driving the backhoe in the open-air
選択できるようにすることで，操作者の操作負担を軽減し，遠 隔操作を効率化することができた。

\section{6. ま と}

本論文では，人間型ロボットの汎用的な遠隔操縦装置の開発 を目指して，産業車再を運転する人間型ロボットの遠隔操縦一 適用し，開発した遠隔操縦装置の構成と，運転作業を円滑に行 うための遠隔操作手法について述べた。開発した遠隔操縦装置 は，分解して現場に運べる可搬型であり，人間型ロボットを操 縦する基本的な機能を備えている。また，産業車両の遠隔操縦 実験により，以下の結論を得た。

（1）開発した操作手法により，全身同時動作を実現し，操作者 の負担軽減し，遠隔操作を効率的に行うことができた。

(2) フォークリフトとバックホウの 2 種類の産業車両について, 人間型ロボットを遠隔操作して人間の代わりに運転するこ とができた。

今後, 実作業に適用していくためには，操作者の負担軽減が 重要である. 特に定型作業の負荷を軽減し, 操作者の判断が求 められる非定常作業に集中できることが必要である。そのため には，操作者が指示しなければならない部分のみ遠隔操作とし， 残りはロボットの自律に任せる自律・遠隔融合が必要と考えて おり，今後は，その方向に研究を進めていく。ただし，その場 合も，運転作業に特化して開発するのではなく，運転作業にも 使用可能な汎用的な遠隔操作手法を開発することが目標である.

人間型ロボットは運転以外の能力を持つので，車両を降りて 周囲の状況を確認したり，故障時に点検を行ったりする作業も 期待される。汎用の遠隔操作を目指した開発は，このような運 転以外の作業にも適用可能であり，人間型ロボットの能力を最 大限に引き出す遠隔操作手法として期待される.

謝 辞 本稿の研究は, 経済産業省「人間協調・共存型ロボッ トシステム研究開発プロジェクト」の一環として実施された。経 済産業省，新エネルギー・産業技術総合開発機構，（財）製造科 学技術センター, (独) 産業技術総合研究所, 東急建設 (株), 京 都大学吉川・横小路研究室をはじめ,ご協力いただきました多 くの方々に感謝いたします.

\section{参 考 文 献}

[1] J. Yamaguchi, E. Soga, S. Inoue and A. Takanishi: "Development of a Bipedal Humanoid Robot-Control Method of Whole Body Cooperative Dynamic Biped Walking," Proc. IEEE Int. Conf. Robotics and Automation, pp.368-374, 1999.

[2] K. Nishiwaki, T. Sugihara, S. Kagami, F. Kanehiro, M. Inaba and H. Inoue: "Design and Development of Research Platform for Perception-Action Intergration in Humanoid Robot: H6," Proc. Int. Conference on Intelligent Robots and Systems, pp.1559-1564, 2000.

[3] M. Gieneger, K. Löffler and F. Pfeiffer: "Towards the Design of Biped Jogging Robot," Proc. IEEE Int. Conf. on Robotics and Automation, pp.4140-4145, 2001.

[4] T. Furuta, Y. Okomura and K. Tomiyama: "Design and Construction of a Series of Compact Humanoid Robots and Development of Biped Walk Control Strategies," CD-ROM Proc. IEEE-RAS Int. Conf. Humanoid Robots, p.84(pdf), 2000

[5] K. Hirai, M. Hirose, Y. Haikawa and T. Takenaka: "The Development of Honda Humanoid Robot," Proc. IEEE Int. Conf. 
on Robotics and Automation, pp.1321-1326, 1998.

[6] M. Hirose, Y. Haikawa, T. Takenaka and K. Hirai: "Development of Humanoid Robot ASIMO," Proc. Int. Conf. on Intelligent Robots and Systems, Workshop2 (Oct. 29), 2001.

[ 7 ] H. Inoue, S. Tachi, Y. Nakamura, K. Hirai, N. Ohyu, S. Hirai, K. Tanie, K. Yokoi and H. Hirukawa: "Overview of $\mathrm{Hu}^{-}$ manoid Robotics of METI," Proc. the 32nd Int. Symposium on Robotics, pp.1478-1482, 2001

[8 ] 横井, 中嶋, 小林, 蓮沼, 御舩, 柳原, 上野, 遠藤, 後久: “人間型 ロボットによる着座型産業車両の代行運転”, 第 8 回口ボティクスシ ンポジア予稿集, pp.264-269, 2003

[ 9 ] 高瀬:“テレオペレーションの過去と末来”, 日本ロボット学会誌, vol.21, no.3, pp.225-228, 2003

[10] 中嶋, 上西, 伊藤, 五百井：“等慣性マスタアームとマスタスレーブ システムの開発”，川崎重工技報，no.101, pp.15-22, 1988 ,

[11] 大築, 真鍋, 石見, 中嶋, 水野, 猪熊：“水中マニピュレーションシ ステムの開発”, 川崎重工技報, no.110, pp.25-33, 1991

[12] 大築, 片岡，桂川，中嶋：“パラレルマニピュレータの力制御”，第 11 回日本ロボット学会学術講演会子稿集, pp.873-874, 1993.

[13] H. Hasunuma, H. Kagaya, M. Koyama, J. Fujimori, H Mihune, H. Moriyama, M. Kobayashi, T. Itoko and S. Tachi
"Tele-operation Master-arm with Gripping Operation Devices," Proc. 9th Int. Conf. Machine Automation, pp.567-572, 2000.

[14] H. Hasunuma, M. Kobayashi, H. Moriyama, T. Itoko, Y Yanagihara, T. Ueno, K. Ohya and K. Yokoi: "A Tele-operated Humanoid Robot Drives a Lift Truck," Proc. IEEE Int. Conf. Robotics and Automation, pp.2246-2252, 2002.

[15] 中嶋, 家中, 藤森, 加賀谷, 森山, 蓮沼, 久保田, 志子田：“可搬型 遠隔制御装置の開発（HRP 代行運転分野）”，日本ロボット学会創立 20 周年記念学術講演会予稿集，2D16,2002。

[16] 宮崎, 荻原：“バイラテラル・マスタ・スレーブ・マニピュレータの並列 型制御方式”, 日本ロボット学会誌, vol.7, no.5, pp.446-452, 1989

[17] W. R. Ferell and T. B. Sheridan: "Supervisory control of remote manipulation," IEEE Spectrum, pp.81-88, 1967.

[18] 平井："Shared Autonomy の理論”, 日本ロボット学会誌, vol.11, no.6, pp.788-793, 1993.

[19] 蓮沼, 中嶋, 小林, 御舩, 宮原, Sian, 横井：“人間型ロボットの遠 隔操作手法の開発（HRP 代行運転分野)”、日本ロボット学会創立 20 周年記念学術講演会予稿集, $2 \mathrm{D} 17,2002$

[20] 小林，樹野，松山，小久保：“人間型双腕マニピュレータの順運動学 と逆運動学”，法政大学計算センター研究報告，9, pp.43-50, 1996

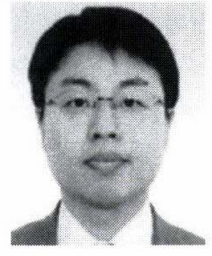

蓮沼仁志（Hitoshi Hasunuma）

1968 年 1 月 1 日生. 1993 年京都大学大学院修上課 程工学研究科応用システム科学専攻修了。同年川崎 重工業株式会社に入社. マイクロマシン, 遠隔操作 ロボットシステムの研究開発に従事. 現在, システ ム技術開発センター第二開発部先進メカトログルー プ主事.

(日本ロボット学会正会員)

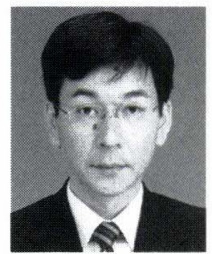

小林政巳 (Masami Kobayashi)

1965 年 2 月 5 日生. 1990 年明治大学大学院工学研 究科修士課程修了。同年川崎重工業株式会社に入社. 2003 年 4 月より新エネルギー・産業技術総合開発 機構に出向. 工学博士. 人工知能の産業応用, オフ ライン教示システム，遠隔操作ロボットシステムの 研究開発に従事. 2001 年日本ロボット学会寒用化 技術賞受賞. 日本機械学会, 人工知能学会の会員.

(日本ロボット学会正会員)

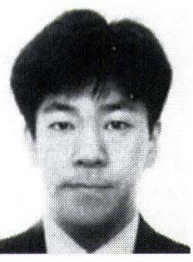

宮原啓造（Keizo Miyahara）

1964 年 11 月 13 日生. 1991 年神戸大学大学院自然 科学研究科修士課程修了. 同年川崎重工業株式会 社に入社. 各種メカトロニクスシステムの研究に従 事. 1997 年 Johns Hopkins 大学機械工学科修士課 程入学. 1999 年同修了。移動メカニズム, 工学系 逆問題に興味を持つ。システム技術開発センター第 二開発部先進メカトログループ主事. IEEE，農業機械学会の会員. Ph.D.

(日本ロボット学会正会員)

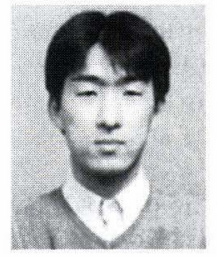

森山 尚（Hisashi Moriyama）

1972 年 8 月 29 日生. 1998 年筑波大学大学院博士課 程工学研究科知能機能工学専攻中退 (工学修士). 同 年川崎重工業株式会社に入社。機構シミュレーショ ン・制御装置のシステム設計に従事。現在システム 技術開発センター第二開発部先進メカトログルー プ. 計測自動制御学会の会員.

(日本ロボット学会正会員)

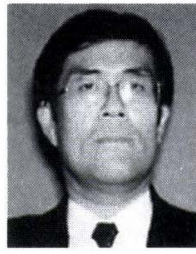

中鴆勝己（Katsumi Nakashima）

1956 年 9 月 28 日生. 1981 年京都大学大学院修士 課程工学研究科精密工学専攻修了. 同年川崎重工業 株式会社に入社、ロボット，自動化装置のシステム 開発，機構開発に従事。現在，システム技術開発七 ンター第二開発部先進メカトログループ参与.

(日本ロボット学会正会員)

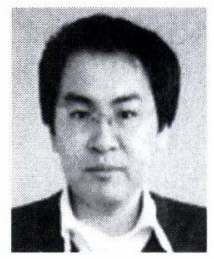

御舩文里 (Humisato Mihune)

1964 年 9 月 7 日生. 1990 年大阪大学大学院博士課 程前期基礎工学研究科物理系機械工学分野専攻修 了. 同年川崎重工業株式会社に入社.ロボット, 自 動化装置のシステム開発に従事. 現在, システム技 術開発センター第二開発部先進メカトログループ主 事.

(日本ロボット学会正会員)

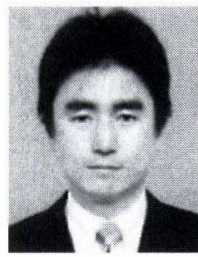

鷹取正夫（Masao Takatori）

1966 年 9 月 15 日生. 1989 年青山学院大学理工学部 機械工学科卒業. 同年川崎重工業株式会社に入社. メカトロニクス製品の開発に従事. 現在システム技 術開発センター第二開発部先進メカトログループ主 事. 日本機械学会の会員.

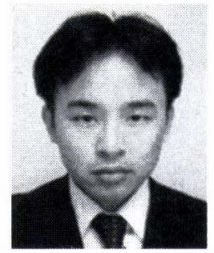

\section{家中良太（Ryota Ienaka）}

1974 年 7 月 11 日生. 1999 年筑波大学大学院博士 課程工学研究科知能機能工学専攻中退 (工学修士). 同年川崎重工業株式会社に入社.メカトロニクス 製品の機構設計に従事. 現在システム技術開発セン ター第二開発部先進メカトログループ.

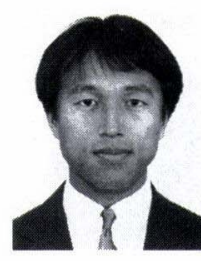

横井一仁（Kazuhito Yokoi）

1961 年 11 月 11 日生. 1986 年東京工業大学大学院 機械物理工学専攻修了. 博士 (工学). 1986 年工業 技術院機械技術研究所に入所. 1995 1996 年ス夕 ンフォード大学客員研究員. 2001 年産業技術総合研 究所知能システム研究部門主任研究員. 神奈川工科 大学連携大学院助教授, 東京工業大学非常勤講師併 任. 人間協調・共存型ロボットシステムプロジェクトに従事. IEEE, 日本機械学会の会員.

(日本ロボット学会正会員) 